\title{
Phenotyping Winter Dormancy in Switchgrass to Extend the Growing Season and Improve Biomass Yield
}

\author{
Rasyidah Mohamad Razar, Ali Missaoui \\ Institute of Plant Breeding Genetics \& Genomics, University of Georgia, Athens, GA, USA \\ Email: cssamm@uga.edu
}

How to cite this paper: Razar, R.M. and Missaoui, A. (2018) Phenotyping Winter Dormancy in Switchgrass to Extend the Growing Season and Improve Biomass Yield. Journal of Sustainable Bioenergy Systems, 8, 1-22.

https://doi.org/10.4236/jsbs.2018.81001

Received: December 28, 2017

Accepted: March 25, 2018

Published: March 28, 2018

Copyright $\odot 2018$ by authors and Scientific Research Publishing Inc. This work is licensed under the Creative Commons Attribution International License (CC BY 4.0).

http://creativecommons.org/licenses/by/4.0/

\section{(c) (i) Open Access}

\begin{abstract}
Switchgrass is a prominent bioenergy crop. Like most perennial warm season species, switchgrass undergoes growth suspension in winter as a surviving strategy in temperate climates to protect their meristems from cold injuries and dehydration, while storage organs below ground drive spring regrowth when conditions become favourable. In this paper, we describe a reliable phenotyping method for winter dormancy in switchgrass using various traits including regrowth height after clipping in early fall (FRH), senescence percentage, date of spring regrowth (SRD), and flowering date (FD). FRH and senescence percentage appear to be reliable indicators of the onset of winter dormancy, whereby accessions that initiated dormancy early have a low FRH and a high senescence percentage. Even though it is difficult to have an exact assessment of the duration of dormancy because it is hard to determine with precision the date of growth suspension, SRD can be used as a surrogate indicator of the duration. Flowering date showed low correlations with all the traits and biomass yield suggesting that it may not be a reliable indicator for winter dormancy in switchgrass. Combining the variables FRH, senescence, and SRD in a selection index may provide a reliable tool to phenotype winter dormancy in switchgrass. The strong correlation of these variables with biomass yield makes them useful candidates for the manipulation of the duration of dormancy to increase the growing season and consequently improving biomass production. In southern regions with mild winters, it might be possible through intense selection to develop germplasm with much reduced dormancy or even non-dormant switchgrass germplasm.
\end{abstract}

\section{Keywords}

Winter Dormancy, Fall Growth, Senescence, Spring Regrowth, Flowering 


\section{Introduction}

Seasonal changes have a great impact on plant development and crop production. For warm season grasses like switchgrass (Panicum virgatum), the transition from a long-day, hot summer to a short-day cold winter will induce a phenomenon called winter dormancy, defined by the lack of visible growth [1] [2]. It is an adaptive mechanism that plants evolved in their environment of origin to enable survival during threatening environmental conditions [3]. One way a perennial plant become dormant is by terminating meristem growth and becoming unresponsive to growth promoting factors [4]. The suspension of growth is essential because cold winter temperature can have an adverse effect on the normal functions of plants such as photosynthesis, cellular transport, and the ability to deal with reactive oxygen species [5], while impacting the plants indirectly through the formation of intracellular and extracellular ice. Intracellular ice crystals can expand the extracellular space and damage the cell structure, while extracellular ice formation can reduce the availability of water for absorption and thus leading to cell dehydration [6].

Dormancy has been defined and classified with regard to the initial physiological reactions leading to dormancy [7] and the external factors that trigger dormancy [8]. Lang [9] and Lang et al. [7] [10] proposed the terms ecodormancy, paradormancy, and endodormancy to describe three types of dormancy. Ecodormancy is the inhibition of growth by temporary unfavorable environmental conditions. Paradormancy refers to the inhibition of growth by signals from distal organs. Endodormancy results from the inhibition of growth by internal bud signals. Rohde and Bhalerao [4] described endodormancy as "the inability to initiate growth from meristems under favorable conditions".

Winter dormancy in switchgrass is a type of endodormancy where plants sense the changes in the duration of photoperiod and temperature and become dormant. Dormancy is usually accompanied by senescence, a degeneration process resulting from programmed cell death [11]. In switchgrass like all perennials senescence is restricted to the above ground part of the plants and not the meristems and below ground structures that enable the plant to resume growth in spring [11]. Senescence is also accompanied by translocation of nutrients to below ground storage organs and reduction in metabolic activity of the crowns, rhizomes, and associated tiller buds that remain dormant throughout winter [12]. Delaying aerial senescence can lead to extended plant's growing season and significantly increases yield as long as the plant still undergo dormancy and nutrient remobilization [13].

The growth cycle of switchgrass can be partitioned in three major phases, winter dormancy, new regrowth in spring, and flowering in mid-summer [12] [14]. The reserves stored before dormancy will later drive regrowth in spring when conditions become favorable for growth [13]. Switching from the vegetative tiller meristems to reproductive tillers and flowering are driven by the perception of appropriate photoperiod and temperature signals [13]. 
Switchgrass ecotypes or even different cultivars within the same ecotype exhibit variable responses during the fall season as they transition to dormancy. Switchgrass upland ecotypes, which are widely found in northern latitudes, enter dormancy earlier than lowland ecotypes that are adapted mostly to southern parts of North America [15]. Lowland ecotypes remain vegetative longer than the upland ecotypes and thus have higher yield, particularly when grown in southern locations [16]. However, despite being low biomass yielders, the upland ecotypes possess the advantage of being more winter hardy and more resistant to cold temperature [15]. Lowry et al. [17] reported that the upland ecotypes can grow in hardiness zones $2-7$, while lowland ecotypes are limited to the southern zones of $6-10$, but both ecotypes can be found in the transition zone [18]. Eight regional gene pools or cultivar deployment zones were described based on adaptation to different photoperiod and temperatures. These largely differ in the time of spring emergence and flowering, cold and heat tolerance, and the onset of winter dormancy [18] [19].

The principal use of switchgrass since the 1940s has been for pasture and grazing in the Great Plains and eastern region of North America [18]. Its use has shifted since it was chosen as the herbaceous model species for biofuel production by the US Department of Energy (DOE) Biofuel Feedstock Development Program (BFDP) in 1991 [20]. The reasons behind its selection as a model bioenergy species are its high productivity, being native perennial requiring low management practices and cost of production, and its suitability for planting in marginal lands that are unsuited for food and other row crops [21] [22].

Manipulating the onset and duration of winter dormancy is a potential strategy to extend the growing season and increase biomass yield of switchgrass in regions with mild winters such as the Southeastern USA. Developing switchgrass cultivars with a longer duration of vegetative growth by delaying the onset of dormancy in the fall and shortening the duration of dormancy will lead to a higher accumulation of biomass. The challenge is how to phenotype accurately dormancy and what target traits need to be selected for. The objective of this study is to develop a reliable phenotyping approach to characterize winter dormancy in switchgrass, focusing on growth patterns usually observed in herbaceous perennial species that undergo seasonal dormancy. These patterns include the slow growth and senescence that happen in fall prior to dormancy, regrowth initiation of new tillers in early spring, flowering time, and the correlation of these phases with biomass accumulation.

\section{Materials and Methods}

\subsection{Plant Material}

A diverse panel of switchgrass germplasm was used to evaluate the phenotyping approaches. The panel consisted of 36 accessions that included 14 uplands, 17 lowlands, and 5 intermediate ecotypes, in addition to the parents of the mapping populations AP13 $\times$ VS16 (Table 1). The information on population ID, place of 
Table 1. Switchgrass accessions and checks (AP13 and VS16) used in the study to evaluate potential phenotypes for winter dormancy.

\begin{tabular}{|c|c|c|c|c|c|c|c|c|c|}
\hline No. & Plant ID & Population & Origin & Ecotype & No. & Plant ID & Population & Origin & Ecotype \\
\hline 1 & AP13 & Alamo & Georgia & Lowland & 20 & PI315728 & BN-13645-64 & $\begin{array}{c}\text { North } \\
\text { Carolina }\end{array}$ & Intermediate \\
\hline 2 & CitrusCo-FL & Citrus County FL & Florida & Lowland & 21 & PI476291 & T-2099 & Maryland & Intermediate \\
\hline 3 & HSP-FL & $\begin{array}{c}\text { Hillsborough } \\
\text { River State Park } \\
\text { FL }\end{array}$ & Florida & Lowland & 22 & PI476293 & T-2101 & $\begin{array}{l}\text { New } \\
\text { Jersey }\end{array}$ & Intermediate \\
\hline 4 & OSSP-FL & $\begin{array}{l}\text { Oscar Scherer } \\
\text { State Park FL }\end{array}$ & Florida & Lowland & 23 & SPBluff & $\begin{array}{l}\text { Sprewell } \\
\text { Bluff }\end{array}$ & Georgia & Intermediate \\
\hline 5 & PI315723 & BN-8358-62 & $\begin{array}{c}\text { North } \\
\text { Carolina }\end{array}$ & Lowland & 24 & PI315724 & BN-10860-61 & Kansas & Upland \\
\hline 7 & PI315727 & BN-11357-63 & $\begin{array}{l}\text { North } \\
\text { Carolina }\end{array}$ & Lowland & 26 & PI414066 & Grenville & $\begin{array}{c}\text { New } \\
\text { Mexico }\end{array}$ & Upland \\
\hline 8 & PI414065 & BN-14668-65 & Arkansas & Lowland & 27 & PI414067 & BN-8624-67 & $\begin{array}{c}\text { North } \\
\text { Carolina }\end{array}$ & Upland \\
\hline 9 & PI414070 & BN-12323-69 & Kansas & Lowland & 28 & PI414068 & BN-18758-67 & Kansas & Upland \\
\hline 10 & PI421521 & Kanlow & Oklahoma & Lowland & 29 & PI421138 & Carthage & $\begin{array}{c}\text { North } \\
\text { Carolina }\end{array}$ & Upland \\
\hline 11 & PI421999 & AM-314/MS-155 & Arkansas & Lowland & 30 & PI421520 & Blackwell & Oklahoma & Upland \\
\hline 12 & PI422001 & Stuart & Florida & Lowland & 31 & PI431575 & KY 1625 & $\begin{array}{c}\text { West } \\
\text { Virginia }\end{array}$ & Upland \\
\hline 14 & PI422006 & Alamo & Texas & Lowland & 33 & PI476294 & $\mathrm{T}-4613$ & Colorado & Upland \\
\hline 15 & PI422016 & L19 & Florida & Lowland & 34 & PI476295 & $\mathrm{T}-4614$ & Colorado & Upland \\
\hline 16 & PI476290 & T-2086 & $\begin{array}{c}\text { North } \\
\text { Carolina }\end{array}$ & Lowland & 35 & PI476296 & $\mathrm{T}-16971$ & Maryland & Upland \\
\hline 17 & SNF & $\begin{array}{c}\text { Sumter National } \\
\text { Forest }\end{array}$ & $\begin{array}{c}\text { South } \\
\text { Carolina }\end{array}$ & Lowland & 36 & PI642190 & Falcon & $\begin{array}{c}\text { New } \\
\text { Mexico }\end{array}$ & Upland \\
\hline 18 & SWFWMD-FL & $\begin{array}{c}\text { Southwest Florida } \\
\text { Water } \\
\text { Management }\end{array}$ & Florida & Lowland & 37 & PI642191 & Summer & $\begin{array}{l}\text { South } \\
\text { Dakota }\end{array}$ & Upland \\
\hline 19 & PascoCo-FL & Pasco County FL & Florida & Intermediate & 38 & VS16 & Summer & $\begin{array}{l}\text { South } \\
\text { Dakota }\end{array}$ & Upland \\
\hline
\end{tabular}

origin, and ecotype was acquired from the US National Plant Germplasm System webpage [23] and Acharya [24]. The intermediate ecotypes showed mixed morphologies between upland and lowland ecotypes and they originated from the transition zone of the United States.

An average of sixteen genotypes from each accession were clonally replicated three times and planted as single plants in a complete randomized block design, with $90 \mathrm{~cm}$ spacing between the plants. The vegetative ramets were planted at 
the UGA plant science farm in Watkinsville, Georgia $\left(33.87^{\circ} \mathrm{N}-83.53^{\circ} \mathrm{W}\right)$ in 2007 and relocated to the UGA Iron horse Research and Education Center near Watkinsville, Georgia $\left(33.73^{\circ} \mathrm{N}-83.30^{\circ} \mathrm{W}\right)$ in 2015 . Temperature [25] and day length for 2016 [26] for Watkinsville, Georgia are summarized in Figure 1. The highest temperature was recorded in July $\left(32.0^{\circ} \mathrm{C}\right)$ and the longest day occurred in June $(14.4 \mathrm{~h})$, while the lowest temperature and shortest day were observed in January $\left(0.2^{\circ} \mathrm{C}\right)$ and December $(9.9 \mathrm{~h})$, respectively.

\subsection{Dormancy Phenotypic Data}

Dormancy phenotypic data evaluated consisted of 1) Level of senescence (senescence \%) and plant regrowth height after clipping in the fall (FRH), 2) Date of spring regrowth initiation (SRD), 3) Date of flowering (FD), and 4) Dry biomass weight. FRH and senescence \% were measured in 2015 and 2016. The amount of senescence and plant regrowth height after clipping in early fall were considered indicators of seasonal dormancy initiation. Plants that enter dormancy will have a very slow regrowth and start senescing as soon as the photoperiod and temperature drop at the end of summer and early fall. The plants were clipped in early September and the regrowth height (FRH) was measured after four weeks from the clipping date. Senescence was quantified based on image analysis. Individual pictures of switchgrass plants were captured using a camera mounted on a light box to maintain uniformity in lighting condition. The pictures were analyzed using the software Assess 2.0 [27], where percentage of green cover is determined and senescence is calculated by subtracting the percent green cover from $100 \%$ (Figure 2).

Since image analysis is laborious and time consuming, we tested a more convenient approach to measure greenness of vegetative cover based on normalized difference vegetation index (NDVI) using a Trimble GreenSeeker handheld crop sensor [28]. The plants were scanned at a fixed height of $120 \mathrm{~cm}$ above the ground. The sensor works by emitting red and infrared lights on plants and then measures the amount of reflected light and converts it to readings ranging from 0.00 to 0.99 . High NDVI values indicate greener plants with a higher vegetative
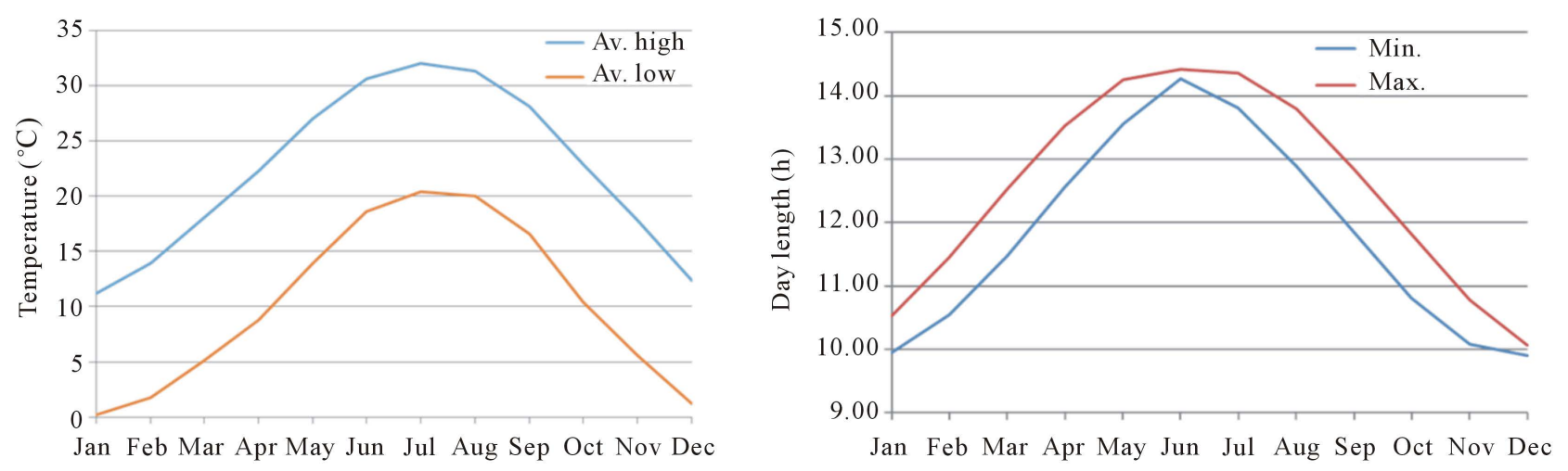

Figure 1. Average minimum and maximum monthly temperature from 1981 to 2010 (left) and 2016 minimum and maximum monthly daylength in Watkinsville, GA (right). 


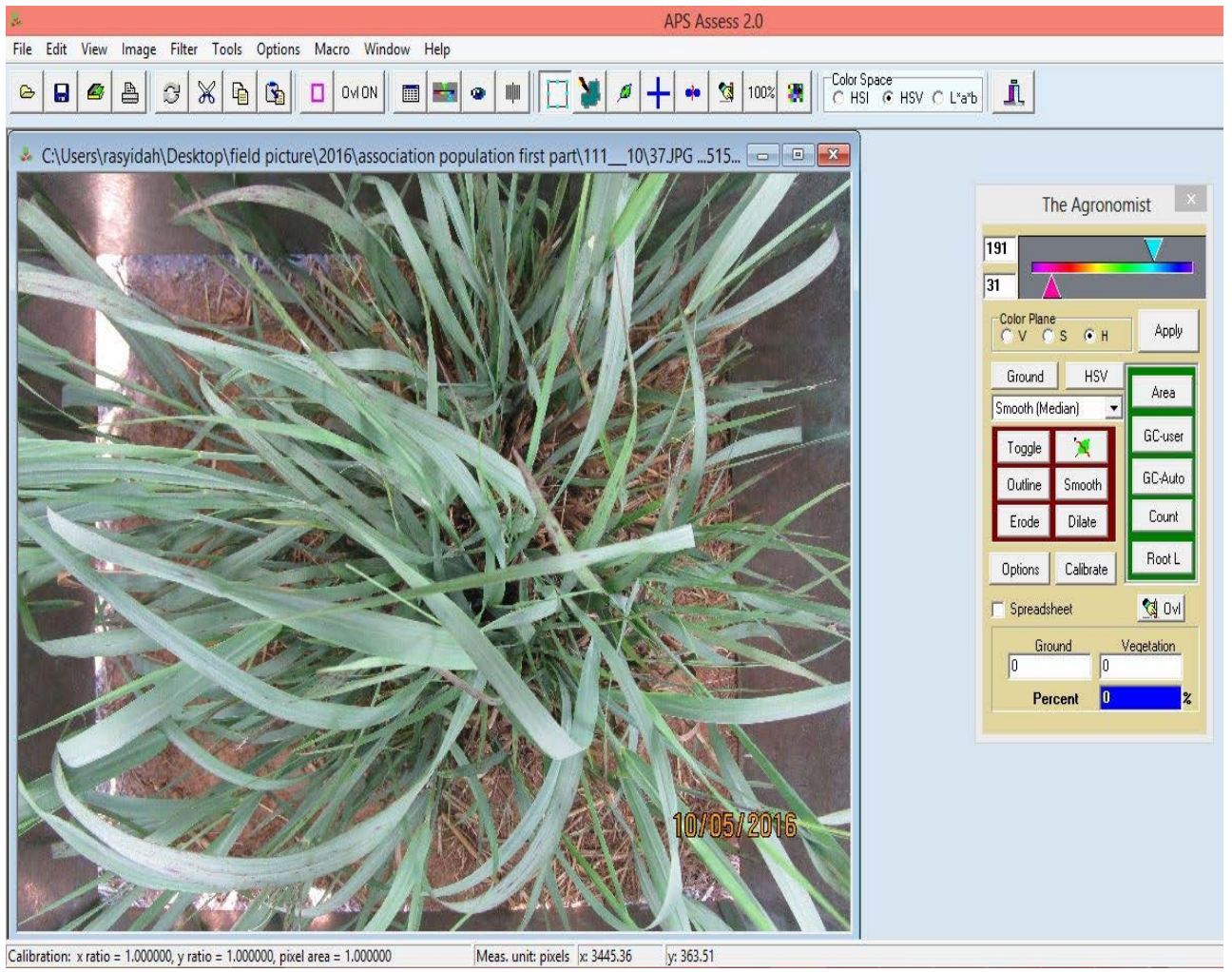

(A)

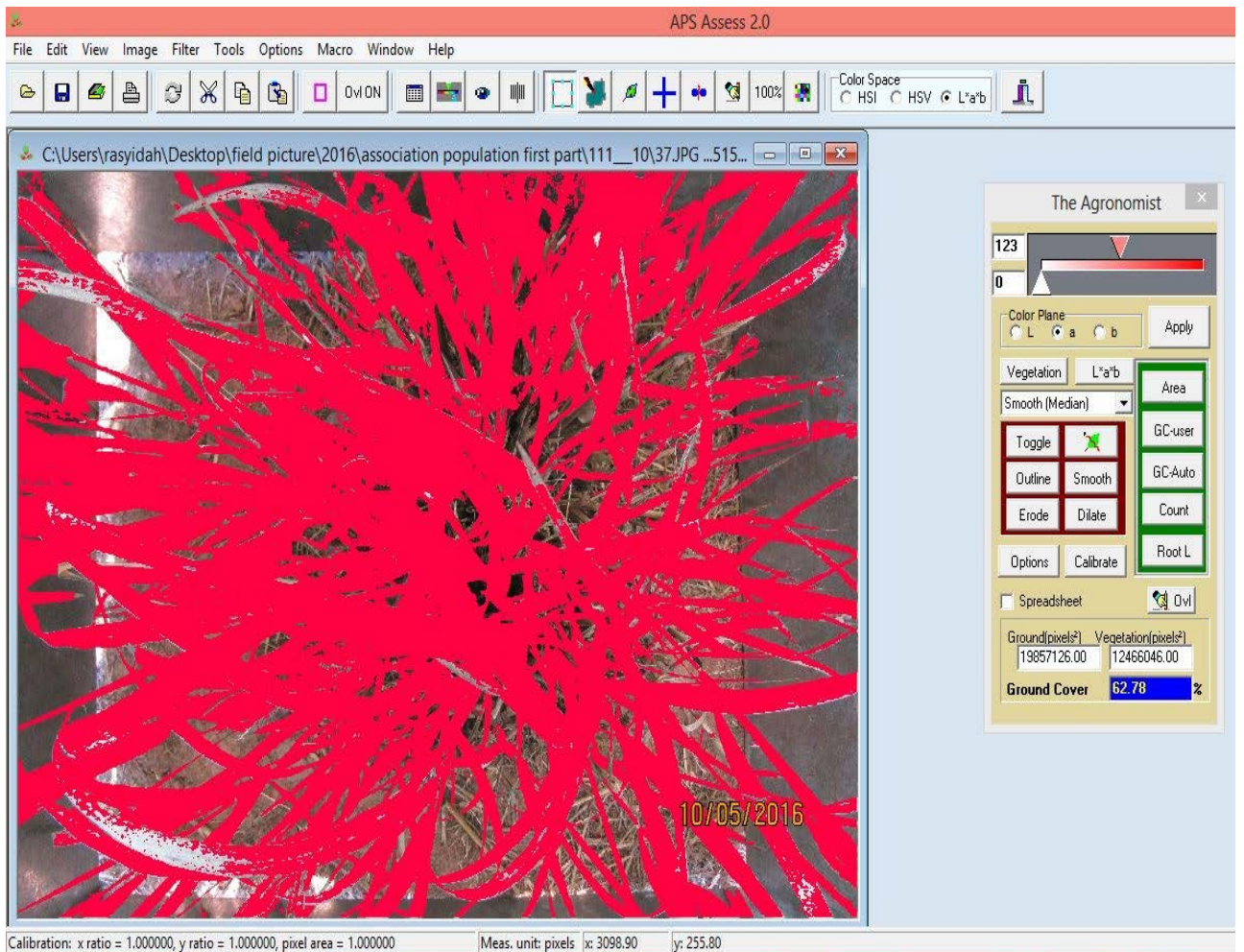

(B)

Figure 2. (A) Normal image captured under a light box; (B) Image generated by the software Assess 2.0 after calculation of percent green cover. The value of vegetative cover in this image is $62.78 \%$ and the senescence percentage is $37.22 \%$. 
cover (lower senescence). NDVI was recorded in 2016 and the correlation with senescence $\%$ was calculated.

To measure the exit time from dormancy, spring regrowth initiation was recorded weekly starting the first week of February until the end of April by observing the emergence of new tillers. SRD was evaluated in 2012 and 2016 and the dates were converted to Julian calendar days, where the earliest regrowth has the smallest Julian date. Flowering date was recorded as inflorescence exertion in at least one culm, from early May to the end of July in 2011 and 2012.

Biomass yield was measured by clipping the plants in early September at the height of $10 \mathrm{~cm}$ above the ground. The harvested plant material was bagged and weighed for fresh weight, then dried in a convection oven at $60^{\circ} \mathrm{C}$ for 5 days and finally weighed for dry weight. Pearson correlations between the various phenotypic scores were calculated to test their impact on the plant biomass yield.

\subsection{Data Analysis}

The data was analyzed using the Proc Mixed procedure in SAS 9.4 for windows (SAS Institute Inc., Cary, NC, 2002-2012). Means were separated using Fisher's protected LSD. To test for normality, the data were initially plotted as histograms and overlaid with normal continuous fit using JMP®, Version 13 (SAS Institute Inc., Cary, NC, 1989-2007). Normal quantile plots were given to illustrate if the population follows a normal distribution pattern (residual points fall closely on the reference line). Since the phenotypic traits being measure are most likely quantitative and controlled by multiple loci, it is desirable to have a normal distribution to make the statistical inferences realistic, especially that the data generated will be used further for QTL mapping.

\section{Results}

Fall regrowth height data showed a normal distribution with a slight left skewness, signifying a high proportion of lower FRH values in the population (Figure 3(A)). Senescence \% distribution was also normal but skewed to the right, indicating a high proportion of higher senescence values in the population (Figure $3(B)$ ). This is expected because most of the upland and intermediate genotypes enter dormancy and senesce much earlier than lowland accessions. The data distribution for SRD was normal but with some outliers in both tails (Figure 3(C)). For FD, the distribution was less bell-shaped and left skewed, suggesting a wide window of flowering and a large variation of flowering dates in the population (Figure 3(D)).

Mean FRH after clipping was significantly different $(\mathrm{p}<0.01)$ between the 36 accessions and two checks (Table 2). The highest mean regrowth height was recorded in a lowland accession SNF $(59.29 \pm 2.70 \mathrm{~cm}$ in 2015 and $60.69 \pm 2.70$ $\mathrm{cm}$ in 2016), while the lowest FRH was seen in an upland accession PI642191 $(13.89 \pm 2.80 \mathrm{~cm}$ in 2015 and $28.37 \pm 2.95 \mathrm{~cm}$ in 2016) (Table 3). There was a significant interaction $(\mathrm{p}<0.01)$ between accessions and years but this was due 


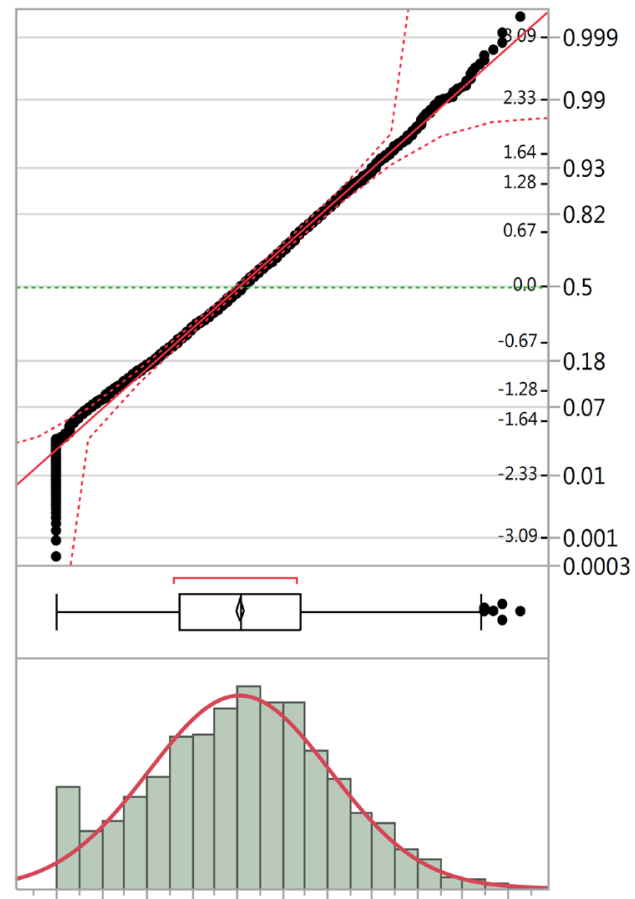

$\begin{array}{lllllllllll}0 & 10 & 20 & 30 & 40 & 50 & 60 & 70 & 80 & 90 & 100\end{array}$

— Normal(40.7147,20.196)

(A)

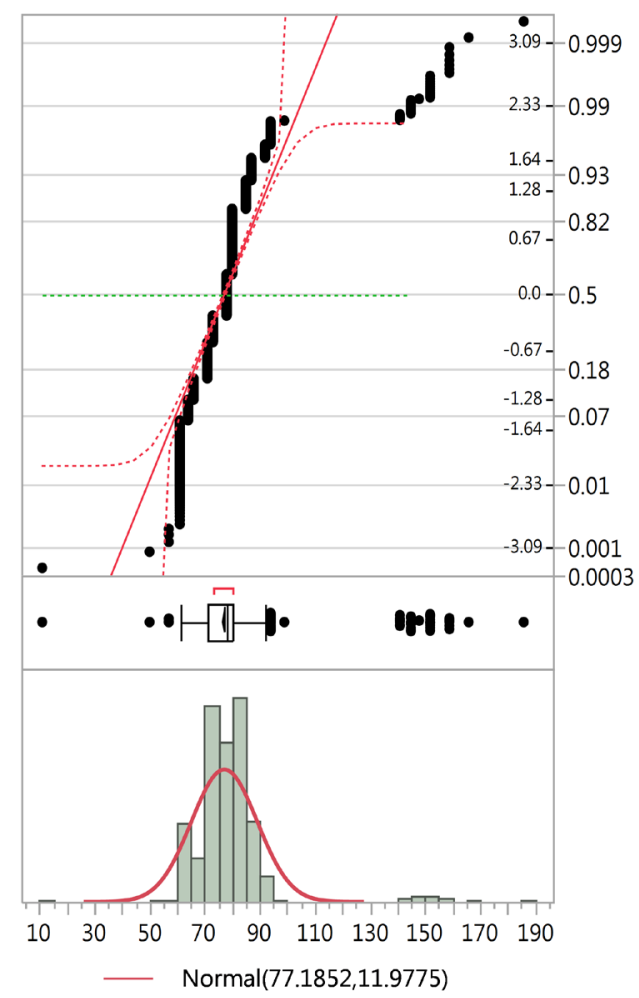

(C)

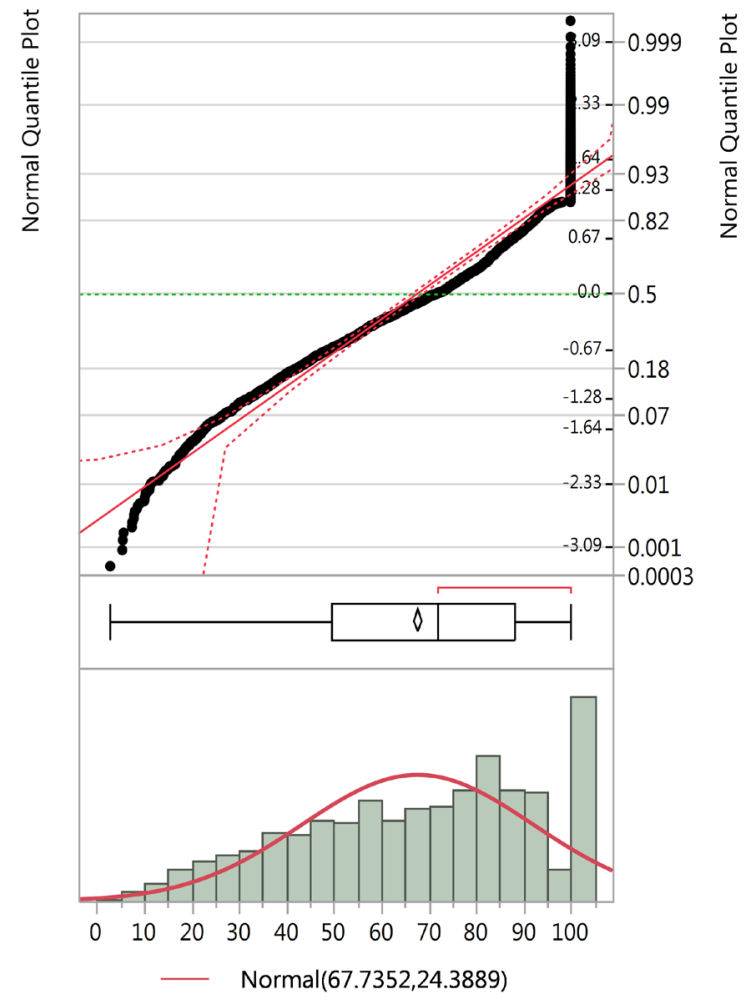

(B)

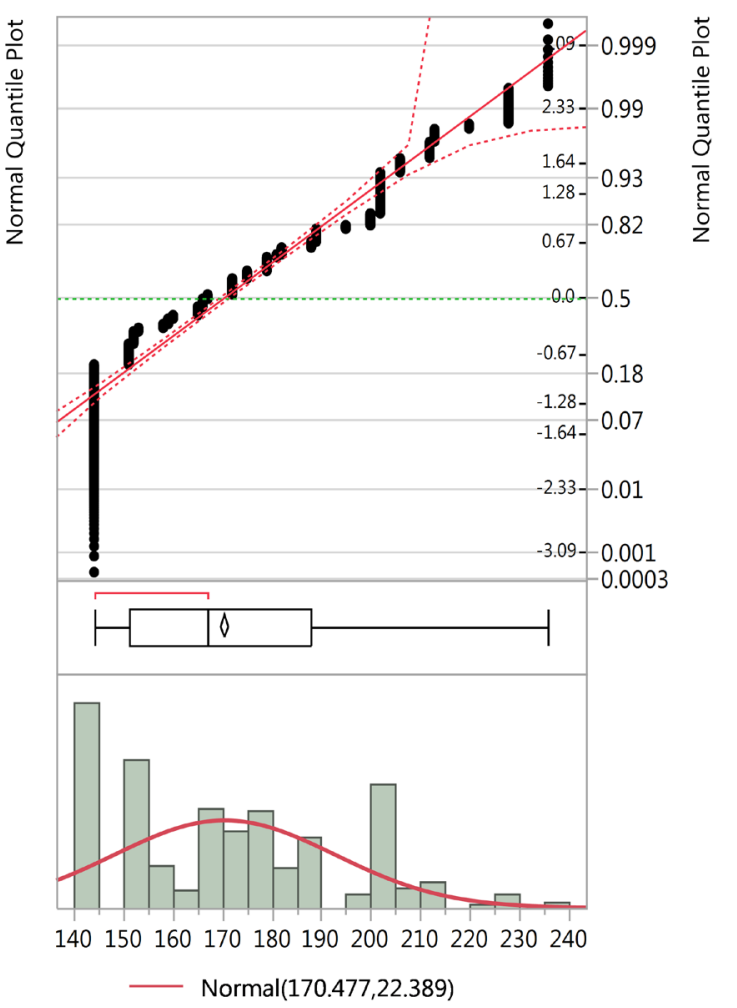

(D)

Figure 3. Histogram with overlay normal continuous fit and normal quantile plot for: (A) Fall regrowth height (cm); (B) Senescence \%; (C) SRD; and (D) FD. 
Table 2. Mean squares and significance of fall regrowth height after clipping (FRH), senescence \%, NDVI, spring regrowth date (SRD), flowering date (FD), and biomass dry weight in 36 switchgrass accessions and two checks.

\begin{tabular}{|c|c|c|c|c|}
\hline \multirow{2}{*}{ Source of variation } & \multicolumn{2}{|c|}{ Fall regrowth height } & \multicolumn{2}{|c|}{ Senescence \% } \\
\hline & Df & Mean square & Df & Mean square \\
\hline Accessions & 37 & $5459^{* *}$ & 37 & $17728^{\star *}$ \\
\hline Year & 1 & $28110^{\star *}$ & 1 & $0.4532 \mathrm{~ns}$ \\
\hline Block & 2 & $804 \mathrm{~ns}$ & 2 & $12499^{* *}$ \\
\hline accessions $^{\star}$ Year & 37 & $1200^{* *}$ & 37 & $4988^{\star *}$ \\
\hline Error & 2224 & 297 & 4580 & 403 \\
\hline \multirow{2}{*}{ Source of variation } & \multicolumn{2}{|c|}{ NDVI } & \multicolumn{2}{|c|}{ Spring regrowth date } \\
\hline & Df & Mean square & Df & Mean square \\
\hline Accessions & 37 & $0.17^{\star *}$ & 37 & $1597^{\star *}$ \\
\hline Year & \multicolumn{2}{|r|}{ na } & 1 & $3644^{\star *}$ \\
\hline Block & 2 & $0.40^{* *}$ & 2 & $1537^{\star *}$ \\
\hline Accessions ${ }^{\star}$ Year & \multicolumn{2}{|r|}{ na } & 37 & $291^{\star *}$ \\
\hline Error & 1032 & 0.02 & 2320 & 114 \\
\hline \multirow{2}{*}{ Source of variation } & \multicolumn{2}{|c|}{ Flowering date } & \multicolumn{2}{|c|}{ Dry weight } \\
\hline & Df & Mean square & Df & Mean square \\
\hline Accessions & 37 & $14247^{\star \star}$ & 31 & $8.87^{* *}$ \\
\hline Year & 1 & $30373^{* *}$ & 1 & $0.88 \mathrm{~ns}$ \\
\hline Block & 2 & $783^{*}$ & 2 & $0.14 \mathrm{~ns}$ \\
\hline Accessions ${ }^{\star}$ Year & 37 & $1883^{* *}$ & 31 & $0.80 \mathrm{~ns}$ \\
\hline Error & 2366 & 223 & 1322 & 0.57 \\
\hline
\end{tabular}

${ }^{*}$ Significant at $\mathrm{p}<0.01,{ }^{*}$ Significant at $\mathrm{p}<0.05, \mathrm{~ns}=$ Non-significant, $\mathrm{na}=$ Not applicable.

mostly to the year effects rather than changes in ranking of the genotypes. Over the two years, the lowland accessions showed the highest regrowth height (46.17 $\pm 0.84 \mathrm{~cm}$ in 2015 and $49.67 \pm 0.88 \mathrm{~cm}$ in 2016) while the upland accessions had the lowest regrowth $(27.97 \pm 0.94 \mathrm{~cm})$ (Figure $4(\mathrm{~A})$ ). The intermediate accessions exhibited higher regrowth height than the upland, but were lower than the lowland accessions $(37.18 \pm 1.59 \mathrm{~cm})$ (Figure 4(A)).

Senescence percentage based on image analysis was significantly different $(\mathrm{p}<$ $0.01)$ between the accessions and showed a significant $(\mathrm{p}<0.01)$ interaction between years and accessions (Table 2). The highest senescence percentage in 2015 was recorded in the lowland accession CitrusCo-FL (91.27 $\pm 3.80 \%)$ and in 2016 in an intermediate accession PascoCo-FL ( $87.56 \pm 3.05 \%$ ) (Table 4). The lowest senescence percentage in 2015 was recorded in a lowland accession PI315723 $(38.09 \pm 2.66 \%)$ and in 2016 in a lowland accession SNF (44.27 $\pm 2.74 \%)$. On average, Upland ecotypes had the highest senescence percentage in 2015 (76.27 $\pm 0.78 \%)$ and intermediate ecotypes had the highest senescence percentage in 
Table 3. Mean fall regrowth height after clipping (FRH) $(\mathrm{cm})$ in 36 switchgrass accessions and two checks (AP13 and VS16).

\begin{tabular}{|c|c|c|c|}
\hline Ecotype & Accessions & 2015 & 2016 \\
\hline \multirow{18}{*}{ Lowland } & AP13 & $40.67 \pm 9.95$ & $41.33 \pm 9.95$ \\
\hline & CitrusCo-FL & $19.99 \pm 4.47$ & $43.47 \pm 4.99$ \\
\hline & HSP-FL & $58.78 \pm 2.64$ & $58.47 \pm 2.76$ \\
\hline & OSSP-FL & $32.57 \pm 3.04$ & $45.22 \pm 3.70$ \\
\hline & PI315723 & $44.15 \pm 2.64$ & $48.42 \pm 2.61$ \\
\hline & PI315725 & $45.32 \pm 7.05$ & $30.67 \pm 7.05$ \\
\hline & PI315727 & $38.70 \pm 2.76$ & $30.05 \pm 3.08$ \\
\hline & PI414065 & $54.02 \pm 2.61$ & $50.08 \pm 2.64$ \\
\hline & PI414070 & $48.76 \pm 2.61$ & $48.90 \pm 2.70$ \\
\hline & PI421521 & $50.64 \pm 2.80$ & $49.95 \pm 2.83$ \\
\hline & PI421999 & $57.66 \pm 2.70$ & $59.36 \pm 2.83$ \\
\hline & PI422001 & $31.56 \pm 3.62$ & $50.33 \pm 4.09$ \\
\hline & PI422003 & $39.74 \pm 2.87$ & $45.74 \pm 3.13$ \\
\hline & PI422006 & $46.01 \pm 2.73$ & $51.48 \pm 2.80$ \\
\hline & PI422016 & $47.12 \pm 2.87$ & $51.92 \pm 2.91$ \\
\hline & PI476290 & $43.22 \pm 2.70$ & $41.79 \pm 2.80$ \\
\hline & SNF & $59.29 \pm 2.70$ & $60.69 \pm 2.70$ \\
\hline & SWFWMD-FL & $23.58 \pm 4.63$ & $59.44 \pm 5.76$ \\
\hline \multirow{5}{*}{ Intermediate } & PascoCo-FL & $25.05 \pm 2.99$ & $33.54 \pm 3.18$ \\
\hline & PI315728 & $38.32 \pm 2.73$ & $36.99 \pm 2.70$ \\
\hline & PI476291 & $35.61 \pm 3.79$ & $46.08 \pm 3.88$ \\
\hline & PI476293 & $28.30 \pm 3.79$ & $30.38 \pm 3.79$ \\
\hline & SPBluff & $32.09 \pm 2.76$ & $39.82 \pm 3.13$ \\
\hline \multirow{15}{*}{ Upland } & PI315724 & $23.07 \pm 3.35$ & $37.10 \pm 4.33$ \\
\hline & PI337553 & $28.17 \pm 2.91$ & $46.30 \pm 3.29$ \\
\hline & PI414066 & $25.15 \pm 2.73$ & $35.75 \pm 3.03$ \\
\hline & PI414067 & $38.10 \pm 2.58$ & $36.22 \pm 2.58$ \\
\hline & PI414068 & $29.10 \pm 3.18$ & $41.40 \pm 3.48$ \\
\hline & PI421138 & $38.85 \pm 2.73$ & $37.48 \pm 2.70$ \\
\hline & PI421520 & $22.60 \pm 2.87$ & $39.07 \pm 2.91$ \\
\hline & PI431575 & $30.16 \pm 3.55$ & $37.09 \pm 3.48$ \\
\hline & PI476292 & $32.93 \pm 2.91$ & $45.33 \pm 2.95$ \\
\hline & PI476294 & $24.93 \pm 3.62$ & $47.39 \pm 3.70$ \\
\hline & PI476295 & $28.73 \pm 3.55$ & $46.71 \pm 4.47$ \\
\hline & PI476296 & $27.62 \pm 3.18$ & $43.06 \pm 3.48$ \\
\hline & PI642190 & $23.54 \pm 3.62$ & $46.04 \pm 3.35$ \\
\hline & PI642191 & $13.89 \pm 2.80$ & $28.37 \pm 2.95$ \\
\hline & VS16 & $16.23 \pm 9.95$ & $62.00 \pm 9.95$ \\
\hline
\end{tabular}

All accessions were significantly different at $\mathrm{p}<0.0001$. Mean FRH is written as $\mathrm{x} \pm$ s.e. 
Table 4. Mean senescence (\%) and NDVI in 36 switchgrass accessions and 2 checks (AP13 and VS16).

\begin{tabular}{|c|c|c|c|c|}
\hline \multirow{2}{*}{ Ecotype } & \multirow{2}{*}{ Accessions } & \multicolumn{2}{|c|}{ Senescence (\%) } & \multirow{2}{*}{$\begin{array}{c}\text { NDVI } \\
2016\end{array}$} \\
\hline & & 2015 & 2016 & \\
\hline \multirow{18}{*}{ Lowland } & AP13 & $73.48 \pm 9.12$ & $82.53 \pm 8.35$ & $0.32 \pm 0.09$ \\
\hline & CitrusCo-FL & $91.27 \pm 3.80$ & $73.86 \pm 4.40$ & $0.31 \pm 0.05$ \\
\hline & HSP-FL & $38.25 \pm 2.70$ & $47.86 \pm 2.77$ & $0.52 \pm 0.03$ \\
\hline & OSSP-FL & $77.61 \pm 2.87$ & $71.78 \pm 3.43$ & $0.36 \pm 0.04$ \\
\hline & PI315723 & $38.09 \pm 2.66$ & $62.32 \pm 2.66$ & $0.41 \pm 0.03$ \\
\hline & PI315725 & $59.25 \pm 6.01$ & $86.93 \pm 6.01$ & $0.26 \pm 0.07$ \\
\hline & PI315727 & $67.39 \pm 2.72$ & $84.38 \pm 3.02$ & $0.26 \pm 0.03$ \\
\hline & PI414065 & $52.74 \pm 2.66$ & $62.33 \pm 2.68$ & $0.40 \pm 0.03$ \\
\hline & PI414070 & $56.06 \pm 2.66$ & $64.72 \pm 2.74$ & $0.37 \pm 0.03$ \\
\hline & PI421521 & $55.35 \pm 2.79$ & $68.78 \pm 2.81$ & $0.36 \pm 0.03$ \\
\hline & PI421999 & $48.20 \pm 2.77$ & $60.08 \pm 2.77$ & $0.43 \pm 0.03$ \\
\hline & PI422001 & $83.21 \pm 2.72$ & $61.77 \pm 3.72$ & $0.39 \pm 0.04$ \\
\hline & PI422003 & $62.12 \pm 2.87$ & $61.10 \pm 3.05$ & $0.42 \pm 0.03$ \\
\hline & PI422006 & $56.86 \pm 2.77$ & $56.32 \pm 2.79$ & $0.44 \pm 0.03$ \\
\hline & PI422016 & $47.15 \pm 2.81$ & $54.02 \pm 2.87$ & $0.45 \pm 0.03$ \\
\hline & PI476290 & $54.15 \pm 2.74$ & $70.60 \pm 2.81$ & $0.33 \pm 0.03$ \\
\hline & SNF & $38.73 \pm 2.72$ & $44.27 \pm 2.74$ & $0.52 \pm 0.03$ \\
\hline & SWFWMD-FL & $88.40 \pm 3.90$ & $60.71 \pm 5.13$ & $0.39 \pm 0.05$ \\
\hline \multirow{5}{*}{ Intermediate } & PascoCo-FL & $76.83 \pm 3.02$ & $87.56 \pm 3.05$ & $0.22 \pm 0.03$ \\
\hline & PI315728 & $60.32 \pm 2.70$ & $78.12 \pm 2.74$ & $0.29 \pm 0.03$ \\
\hline & PI476291 & $64.73 \pm 3.43$ & $71.76 \pm 3.64$ & $0.35 \pm 0.04$ \\
\hline & PI476293 & $87.52 \pm 3.32$ & $84.02 \pm 3.49$ & $0.22 \pm 0.04$ \\
\hline & SPBluff & $68.94 \pm 2.74$ & $71.52 \pm 3.09$ & $0.32 \pm 0.03$ \\
\hline \multirow{15}{*}{ Upland } & PI315724 & $86.31 \pm 3.22$ & $70.98 \pm 3.90$ & $0.32 \pm 0.04$ \\
\hline & PI337553 & $84.51 \pm 2.95$ & $67.86 \pm 3.17$ & $0.35 \pm 0.03$ \\
\hline & PI414066 & $80.28 \pm 2.79$ & $77.54 \pm 2.95$ & $0.28 \pm 0.03$ \\
\hline & PI414067 & $60.32 \pm 2.66$ & $71.60 \pm 2.65$ & $0.35 \pm 0.03$ \\
\hline & PI414068 & $78.27 \pm 3.09$ & $72.70 \pm 3.27$ & $0.30 \pm 0.04$ \\
\hline & PI421138 & $61.64 \pm 2.79$ & $71.44 \pm 2.74$ & $0.34 \pm 0.03$ \\
\hline & PI421520 & $86.69 \pm 3.02$ & $78.36 \pm 2.87$ & $0.27 \pm 0.03$ \\
\hline & PI431575 & $76.66 \pm 3.17$ & $70.94 \pm 3.32$ & $0.31 \pm 0.04$ \\
\hline & PI476292 & $74.59 \pm 2.92$ & $64.20 \pm 2.92$ & $0.37 \pm 0.03$ \\
\hline & PI476294 & $82.26 \pm 2.99$ & $67.32 \pm 3.43$ & $0.35 \pm 0.04$ \\
\hline & PI476295 & $90.21 \pm 3.02$ & $71.35 \pm 4.01$ & $0.33 \pm 0.04$ \\
\hline & PI476296 & $84.46 \pm 2.89$ & $71.94 \pm 3.27$ & $0.29 \pm 0.04$ \\
\hline & PI642190 & $89.98 \pm 2.87$ & $66.91 \pm 3.17$ & $0.35 \pm 0.03$ \\
\hline & PI642191 & $88.52 \pm 3.02$ & $81.81 \pm 2.92$ & $0.23 \pm 0.03$ \\
\hline & VS16 & $82.97 \pm 10.17$ & $80.96 \pm 6.55$ & $0.33 \pm 0.09$ \\
\hline
\end{tabular}

All accessions were significantly different at $\mathrm{p}<0.01$. Mean senescence and NDVI are given as mean \pm s.e. 


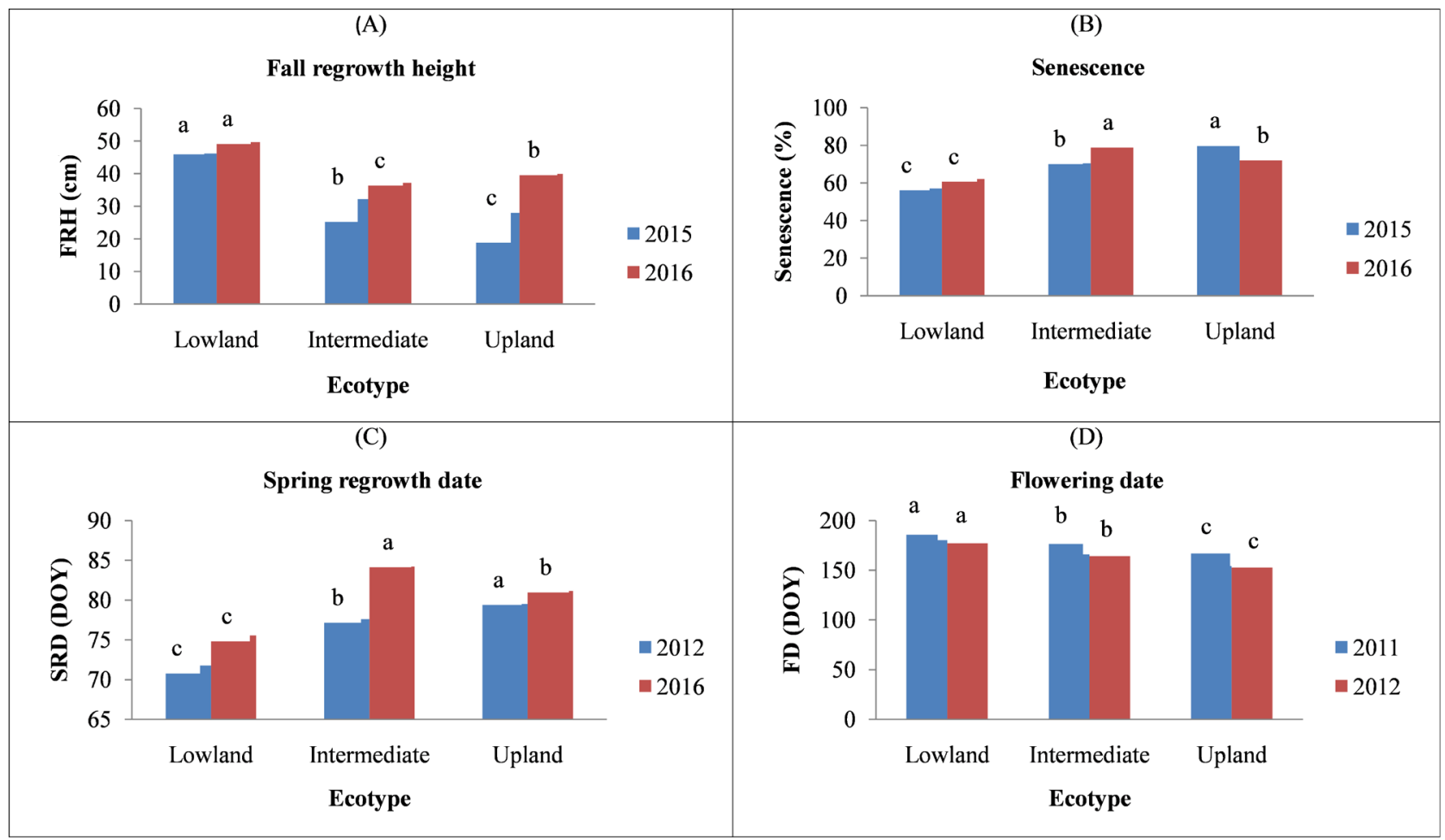

Figure 4. (A) Mean fall regrowth height in $\mathrm{cm}$ (FRH); (B) Mean senescence (\%); (C) Mean spring regrowth date in day of the year (SRD, DOY); and (D) Mean flowering date in day of the year (FD, DOY) in 36 switchgrass and two checks grouped by ecotype (Lowland, Upland, and Intermediate). Ecotypes with the same letters are not significantly different at $\mathrm{p}<0.05$.

$2016(78.80 \pm 2.25 \%)$. Lowland ecotypes had the lowest senescence percentage during both years $(57.04 \pm 1.90 \%$ in 2015 and $62.11 \pm 1.92 \%$ in 2016) (Figure $4(B))$.

NDVI values showed significant differences among accessions $(\mathrm{p}<0.01)$ (Table 2). The highest NDVI value was recorded in the lowland accession HSP-FL $(0.52 \pm 0.03)$, while the lowest NDVI was found in an intermediate ecotype PascoCo-FL $(0.22 \pm 0.03)$ (Table 4$)$. In general, lowland ecotypes have the highest NDVI $(0.40 \pm 0.02)$, followed by upland ecotypes $(0.32 \pm 0.02)$, and the lowest NDVI in intermediate ecotypes $(0.28 \pm 0.02)$.

The date of initiation of spring regrowth (SRD) was significantly different among accessions $(\mathrm{p}<0.01)$ and showed an interaction between years and accessions $(\mathrm{p}<0.01)$ (Table 2). The highest SRD (late spring regrowth initiation) in 2012 was recorded in the upland genotype VS16 (87.00 \pm 6.22$)$ and in 2016 in the upland accession PI642190 (88.41 \pm 2.20$)$ (Table 5). The lowest SRD (early spring regrowth initiation) was recorded in a lowland accession SNF (61.12 \pm 1.82 in 2012 and $67.04 \pm 1.84$ in 2016). Over the two years, the upland ecotypes had the highest SRD in $2012(79.50 \pm 0.90)$ and intermediate ecotypes had the highest SRD in $2016(84.21 \pm 1.20)$. Lowland ecotypes had the lowest SRD for both recording years (71.75 \pm 0.90 in 2012 and $75.54 \pm 0.90$ in 2016) (Figure $4(\mathrm{C})$ ).

Flowering dates were also significantly different among accessions $(\mathrm{p}<0.01)$ 
Table 5. Mean spring regrowth dates (SRD) in day of the year (Julian calendar) in 36 switchgrass accessions and 2 checks (AP13 and VS16).

\begin{tabular}{|c|c|c|c|}
\hline Ecotype & Accessions & 2012 & 2016 \\
\hline \multirow{18}{*}{ Lowland } & AP13 & $77.67 \pm 6.22$ & $75.67 \pm 6.22$ \\
\hline & CitrusCo-FL & $78.77 \pm 2.96$ & $87.72 \pm 3.18$ \\
\hline & HSP-FL & $67.40 \pm 1.82$ & $70.68 \pm 1.84$ \\
\hline & OSSP-FL & $70.15 \pm 2.41$ & $81.90 \pm 2.36$ \\
\hline & PI315723 & $78.18 \pm 1.77$ & $81.51 \pm 1.77$ \\
\hline & PI315725 & $68.33 \pm 4.43$ & $76.83 \pm 4.43$ \\
\hline & PI315727 & $75.21 \pm 1.84$ & $83.50 \pm 2.01$ \\
\hline & PI414065 & $71.04 \pm 1.77$ & $71.50 \pm 1.79$ \\
\hline & PI414070 & $76.67 \pm 1.77$ & $74.35 \pm 1.82$ \\
\hline & PI421521 & $76.77 \pm 1.88$ & $76.91 \pm 1.90$ \\
\hline & PI421999 & $67.76 \pm 1.82$ & $70.62 \pm 1.84$ \\
\hline & PI422001 & $73.69 \pm 3.18$ & $87.91 \pm 2.78$ \\
\hline & PI422003 & $64.11 \pm 1.90$ & $72.03 \pm 2.07$ \\
\hline & PI422006 & $71.78 \pm 1.77$ & $74.49 \pm 1.86$ \\
\hline & PI422016 & $73.43 \pm 1.90$ & $76.71 \pm 1.94$ \\
\hline & PI476290 & $72.78 \pm 1.84$ & $75.60 \pm 1.86$ \\
\hline & SNF & $61.12 \pm 1.82$ & $67.04 \pm 1.84$ \\
\hline & SWFWMD-FL & $79.71 \pm 3.47$ & $76.04 \pm 3.47$ \\
\hline \multirow{5}{*}{ Intermediate } & PascoCo-FL & $75.66 \pm 1.99$ & $88.05 \pm 2.10$ \\
\hline & PI315728 & $80.00 \pm 1.77$ & $85.39 \pm 1.84$ \\
\hline & PI476291 & $74.92 \pm 2.31$ & $79.19 \pm 2.46$ \\
\hline & PI476293 & $79.44 \pm 2.36$ & $83.19 \pm 2.46$ \\
\hline & SPBluff & $77.20 \pm 1.77$ & $83.14 \pm 1.96$ \\
\hline \multirow{15}{*}{ Upland } & PI315724 & $79.28 \pm 1.88$ & $87.70 \pm 2.78$ \\
\hline & PI337553 & $78.00 \pm 1.73$ & $85.40 \pm 2.13$ \\
\hline & PI414066 & $79.98 \pm 1.75$ & $84.69 \pm 1.99$ \\
\hline & PI414067 & $76.10 \pm 1.73$ & $76.98 \pm 1.75$ \\
\hline & PI414068 & $75.85 \pm 1.88$ & $82.28 \pm 2.23$ \\
\hline & PI421138 & $78.17 \pm 1.82$ & $81.10 \pm 1.82$ \\
\hline & PI421520 & $79.69 \pm 1.77$ & $81.35 \pm 1.92$ \\
\hline & PI431575 & $78.23 \pm 2.23$ & $77.80 \pm 2.27$ \\
\hline & PI476292 & $76.70 \pm 1.82$ & $78.31 \pm 1.94$ \\
\hline & PI476294 & $83.93 \pm 2.01$ & $80.49 \pm 2.41$ \\
\hline & PI476295 & $86.56 \pm 2.23$ & $76.34 \pm 2.78$ \\
\hline & PI476296 & $81.62 \pm 2.01$ & $77.60 \pm 2.31$ \\
\hline & PI642190 & $81.61 \pm 1.94$ & $88.41 \pm 2.20$ \\
\hline & PI642191 & $80.99 \pm 1.84$ & $80.95 \pm 1.92$ \\
\hline & VS16 & $87.00 \pm 6.22$ & $78.00 \pm 6.22$ \\
\hline
\end{tabular}

All accessions were significantly different at $\mathrm{p}<0.0001$. Mean $\mathrm{SRD}$ is given as $\mathrm{x} \pm$ s.e. 
and showed an interaction between years and accessions $(\mathrm{p}<0.01)$ (Table 2). The highest values for flowering dates (late flowering dates) were noted on the lowland accession OSSP-FL (213.77 \pm 3.76 in 2011 and $205.68 \pm 4.75$ in 2012) and the lowest values (early flowering dates) was recorded for an upland accession PI476294 in $2011(154.78 \pm 2.53)$ and for an upland accession PI414066 in $2012(144.95 \pm 2.25)$ (Table 6). Finally for FD the highest observation was recorded for lowland ecotypes (185.81 \pm 0.91 in 2011 and $177.14 \pm 0.93$ in 2012) and the lowest observation was seen for upland ecotype (166.88 \pm 0.90 in 2011 and $152.87 \pm 0.94$ in 2012) (Figure 4(D)).

Dry biomass yield was significantly different among accessions $(\mathrm{p}<0.01)$ and there was no significant interaction with years (Table 2). Because of the non-significant accession by year interaction, dry biomass yield was averaged across years (Table 7). The highest dry weight was recorded for the lowland accession SNF $\left(1.91 \pm 0.08 \mathrm{~kg} \cdot \mathrm{plant}^{-1}\right)$ and the lowest dry weight was recorded in an upland accession PI421520 (0.41 $\pm 0.16 \mathrm{~kg} \cdot$ plant $\left.^{-1}\right)$. When averaged across ecotypes, biomass yield showed a significant difference between ecotypes but no significant interaction with years (Table 8). The highest dry weight was recorded for lowland ecotypes $(1.24 \pm 0.02 \mathrm{~kg})$, followed by upland ecotypes $(0.60 \pm 0.04 \mathrm{~kg})$, and the lowest yield was observed in intermediate ecotypes $(0.55 \pm 0.06 \mathrm{~kg})$.

Biomass yield showed a significant positive correlation with fall regrowth height after clipping $(\mathrm{r}=0.6, \mathrm{p}<0.01)$ and flowering date $(\mathrm{r}=0.44, \mathrm{p}<0.01)$, while it was negatively correlated with senescence $\%(r=-0.56, p<0.01)$ and spring regrowth date $(r=0.62, p<0.01)$ (Table 9). Senescence $\%$ based on image analysis showed a highly significant correlation with NDVI $(\mathrm{r}=-0.92, \mathrm{p}<$ 0.01). Fall regrowth height after clipping showed a low positive correlation with date of flowering $(r=0.27 \mathrm{p}<0.05)$ and high negative correlations with senescence $\%(r=-0.79, \mathrm{p}<0.01)$ and SRD $(\mathrm{r}=-0.46, \mathrm{p}<0.01)$. Senescence \% was positively correlated with SRD $(\mathrm{r}=0.58, \mathrm{p}<0.58)$ but showed a low negative correlation with FD $(r=-0.39, \mathrm{p}<0.01)$.

\section{Discussion}

Switchgrass production depends on environmental cues to synchronize growth with favorable environmental conditions, and dormancy is triggered when conditions are unfavorable in winter [17]. Photoperiod and temperature are important factors determining plant metabolism in warm season grasses. Most metabolic pathways such as photosynthesis, respiration, and growth processes are catalyzed by enzymes which activities are influenced by temperature, and thus are affected when temperature drops. Switchgrass growth is much greater under long days than short days [29] and flowering is usually delayed under long days.

Optimal harvest time for switchgrass has been debated, with most studies suggesting early fall season. Delaying harvest to winter may reduce biomass yield by up to $40 \%$ [30]. Johnson and Gresham [31] found a decrease in yield when switchgrass was harvested in spring compared to harvest in fall with significantly 
Table 6. Mean flowering dates (FD) in day of the year (Julian calendar) in 36 switchgrass accessions and 2 checks (AP13 and VS16).

\begin{tabular}{|c|c|c|c|}
\hline \multirow{2}{*}{ Ecotype } & \multirow{2}{*}{ Accessions } & \multicolumn{2}{|c|}{ Flowering date (day of the year) } \\
\hline & & 2011 & 2012 \\
\hline \multirow{20}{*}{ Lowland } & AP13 & $196.00 \pm 8.63$ & $168.00 \pm 8.63$ \\
\hline & CitrusCo-FL & $181.63 \pm 3.76$ & $199.30 \pm 3.89$ \\
\hline & HSP-FL & $190.84 \pm 2.41$ & $190.89 \pm 2.41$ \\
\hline & OSSP-FL & $213.77 \pm 3.76$ & $205.68 \pm 4.75$ \\
\hline & PI315723 & $181.78 \pm 2.28$ & $167.87 \pm 2.30$ \\
\hline & PI315725 & $188.67 \pm 6.11$ & $197.00 \pm 6.11$ \\
\hline & PI315727 & $161.49 \pm 2.30$ & $145.61 \pm 2.47$ \\
\hline & PI414065 & $182.12 \pm 2.30$ & $177.32 \pm 2.33$ \\
\hline & PI414070 & $193.20 \pm 2.28$ & $179.44 \pm 2.28$ \\
\hline & PI421521 & $193.59 \pm 2.44$ & $185.97 \pm 2.44$ \\
\hline & PI421999 & $181.02 \pm 2.35$ & $170.83 \pm 2.35$ \\
\hline & PI422001 & $190.50 \pm 5.00$ & $195.47 \pm 4.34$ \\
\hline & PI422003 & $206.72 \pm 2.91$ & $197.52 \pm 3.29$ \\
\hline & PI422006 & $181.96 \pm 2.28$ & $175.00 \pm 2.28$ \\
\hline & PI422016 & $181.40 \pm 2.47$ & $158.48 \pm 2.47$ \\
\hline & PI476290 & $180.90 \pm 2.35$ & $157.06 \pm 2.38$ \\
\hline & SNF & $192.02 \pm 2.35$ & $201.57 \pm 2.35$ \\
\hline & SWFWMD-FL & $188.69 \pm 5.00$ & $191.05 \pm 5.30$ \\
\hline & PascoCo-FL & $182.94 \pm 2.53$ & $171.11 \pm 3.15$ \\
\hline & PI315728 & $166.82 \pm 2.28$ & $156.26 \pm 2.35$ \\
\hline \multirow[t]{10}{*}{ Intermediate } & PI476291 & $168.92 \pm 3.09$ & $147.25 \pm 3.22$ \\
\hline & PI476293 & $165.63 \pm 2.86$ & $157.93 \pm 3.89$ \\
\hline & SPBluff & $202.53 \pm 2.91$ & $188.07 \pm 2.91$ \\
\hline & PI315724 & $166.03 \pm 2.44$ & $148.55 \pm 2.57$ \\
\hline & PI337553 & $172.94 \pm 2.21$ & $147.52 \pm 2.21$ \\
\hline & PI414066 & $155.82 \pm 2.25$ & $144.95 \pm 2.25$ \\
\hline & PI414067 & $178.67 \pm 2.21$ & $147.48 \pm 2.21$ \\
\hline & PI414068 & $166.03 \pm 2.44$ & $148.29 \pm 2.50$ \\
\hline & PI421138 & $187.50 \pm 2.35$ & $157.13 \pm 2.38$ \\
\hline & PI421520 & $165.89 \pm 2.28$ & $146.07 \pm 2.28$ \\
\hline \multirow[t]{8}{*}{ Upland } & PI431575 & $187.78 \pm 2.97$ & $165.44 \pm 2.91$ \\
\hline & PI476292 & $173.30 \pm 2.33$ & $168.77 \pm 2.33$ \\
\hline & PI476294 & $154.78 \pm 2.53$ & $155.51 \pm 3.02$ \\
\hline & PI476295 & $157.60 \pm 2.68$ & $161.27 \pm 3.02$ \\
\hline & PI476296 & $155.83 \pm 2.47$ & $159.97 \pm 2.77$ \\
\hline & PI642190 & $155.90 \pm 2.47$ & $152.97 \pm 2.86$ \\
\hline & PI642191 & $159.07 \pm 2.35$ & $146.12 \pm 2.91$ \\
\hline & VS16 & $158.67 \pm 8.63$ & $151.64 \pm 14.94$ \\
\hline
\end{tabular}

All accessions were significantly different at $\mathrm{p}<0.0001$. Mean FD is given as $\mathrm{x} \pm$ s.e. 
Table 7. Mean biomass dry weight $(\mathrm{kg})$ in 31 switchgrass accessions and one check (AP13).

\begin{tabular}{|c|c|c|}
\hline Ecotype & Accessions & Biomass yield $(\mathrm{kg})$ \\
\hline & AP13 & $0.75 \pm 0.31$ \\
\hline & HSP-FL & $1.72 \pm 0.09$ \\
\hline & OSSP-FL & $1.02 \pm 0.22$ \\
\hline & PI315723 & $0.79 \pm 0.09$ \\
\hline & PI315725 & $1.44 \pm 0.23$ \\
\hline & PI315727 & $0.51 \pm 0.14$ \\
\hline & PI414065 & $1.38 \pm 0.08$ \\
\hline & PI414070 & $1.11 \pm 0.08$ \\
\hline \multirow[t]{11}{*}{ Lowland } & PI421521 & $1.05 \pm 0.09$ \\
\hline & PI421999 & $1.31 \pm 0.08$ \\
\hline & PI422001 & $0.73 \pm 0.26$ \\
\hline & PI422003 & $1.57 \pm 0.09$ \\
\hline & PI422006 & $1.46 \pm 0.09$ \\
\hline & PI422016 & $0.93 \pm 0.09$ \\
\hline & PI476290 & $0.85 \pm 0.09$ \\
\hline & SNF & $1.91 \pm 0.08$ \\
\hline & SWFWMD-FL & $0.48 \pm 0.34$ \\
\hline & PascoCo-FL & $0.53 \pm 0.22$ \\
\hline & PI315728 & $0.54 \pm 0.12$ \\
\hline \multirow{7}{*}{ Intermediate } & PI476291 & $0.59 \pm 0.13$ \\
\hline & SPBluff & $0.55 \pm 0.09$ \\
\hline & PI315724 & $0.41 \pm 0.16$ \\
\hline & PI337553 & $0.48 \pm 0.13$ \\
\hline & PI414066 & $0.52 \pm 0.16$ \\
\hline & PI414067 & $0.52 \pm 0.09$ \\
\hline & PI414068 & $0.49 \pm 0.20$ \\
\hline \multirow[t]{6}{*}{ Upland } & PI421138 & $0.57 \pm 0.10$ \\
\hline & PI421520 & $0.41 \pm 0.16$ \\
\hline & PI431575 & $1.00 \pm 0.16$ \\
\hline & PI476292 & $0.82 \pm 0.10$ \\
\hline & PI476296 & $0.49 \pm 0.22$ \\
\hline & PI642190 & $1.47 \pm 0.44$ \\
\hline
\end{tabular}

Accessions were significantly different at $\mathrm{p}<0.01$. 
Table 8. Mean squares and significance of fall regrowth height after clipping (FRH), senescence \%, NDVI, spring regrowth date (SRD), flowering date (FD), and biomass dry weight in 36 switchgrass accessions and two checks grouped by ecotype (Lowland, Upland, and Intermediate).

\begin{tabular}{|c|c|c|c|c|}
\hline \multirow{2}{*}{ Source of variation } & \multicolumn{2}{|c|}{ Fall regrowth height } & \multicolumn{2}{|c|}{ Senescence \% } \\
\hline & Df & Mean square & Df & Mean square \\
\hline Ecotype & 2 & $54599.00^{* *}$ & 2 & $147690^{\star *}$ \\
\hline Year & 1 & $19785.00^{* *}$ & 1 & $3661^{\star *}$ \\
\hline Block & 2 & $640.89 \mathrm{~ns}$ & 2 & $15450^{* *}$ \\
\hline Ecotype $e^{\star}$ Year & 2 & $4614.79^{* *}$ & 2 & $23948^{* *}$ \\
\hline Error & 2294 & 344.13 & 4650 & 511 \\
\hline \multirow{2}{*}{ Source of variation } & \multicolumn{2}{|c|}{ NDVI } & \multicolumn{2}{|c|}{ Spring regrowth date } \\
\hline & Df & Mean square & Df & Mean square \\
\hline Ecotype & 2 & $1.35^{\star *}$ & 2 & $13843^{* *}$ \\
\hline Year & \multicolumn{2}{|r|}{ na } & 1 & $7132^{\star *}$ \\
\hline Block & 2 & $0.43^{* *}$ & 2 & $1495^{\star *}$ \\
\hline Ecotype ${ }^{\star}$ Year & \multicolumn{2}{|r|}{ na } & 2 & $778^{* *}$ \\
\hline Error & 1067 & 0.02 & 2390 & 128 \\
\hline \multirow{2}{*}{ Source of variation } & \multicolumn{2}{|c|}{ Flowering date } & \multicolumn{2}{|c|}{ Dry weight } \\
\hline & Df & Mean square & Df & Mean square \\
\hline Ecotype & 2 & $125440^{\star \star}$ & 2 & $67.39^{\star *}$ \\
\hline Year & 1 & $57212^{* *}$ & 1 & $2.66^{*}$ \\
\hline Block & 2 & $795 \mathrm{~ns}$ & 2 & $0.07 \mathrm{~ns}$ \\
\hline Ecotype ${ }^{\star}$ Year & 2 & $1958^{\star *}$ & 2 & $1.19 \mathrm{~ns}$ \\
\hline Error & 2436 & 362 & 1380 & 0.67 \\
\hline
\end{tabular}

${ }^{*}$ Significant at $\mathrm{p}<0.01,{ }^{*}$ Significant at $\mathrm{p}<0.05, \mathrm{~ns}=$ Non-significant, na $=$ Not applicable.

Table 9. Pearson correlation between phenotypic scores of various indicators of winter dormancy in switchgrass.

\begin{tabular}{lccccc}
\hline & 1 & 2 & 3 & 4 & 5 \\
\hline 1) Fall regrowth height & 1.00 & & & \\
2) Senescence $\%$ & $-0.79^{* *}$ & 1.00 & & & \\
3) Spring regrowth date & $-0.46^{* *}$ & $0.58^{* *}$ & 1.00 & & 1.00 \\
4) Flowering date & $0.27^{*}$ & $-0.39^{* *}$ & $-0.51^{* *}$ & $0.44^{* *}$ & $-0.62^{* *}$ \\
5) Dry weight & $0.60^{* *}$ & $-0.56^{* *}$ & -0. & - \\
6) NDVI & - & $-0.92^{* *}$ & - & - \\
\hline
\end{tabular}

higher $\mathrm{N}, \mathrm{P}$, and $\mathrm{S}$ concentration in fall harvest compared to spring harvest [31]. Gamble et al. [32] reported lower biomass yield harvested in winter compared to late summer-fall and late spring. Concentration of $\mathrm{N}$ was not different between 
harvests but $\mathrm{P}$ and $\mathrm{K}$ concentrations were decreased enormously from late summer to late spring harvests [32]. The decrease in biomass yield reported in these studies might be the result of remobilization of nutrients from aboveground structures to belowground storage organs during the onset of dormancy in fall and senescence, leading to a low biomass yield for over-wintered switchgrass plants.

The significant differences observed in our study among accessions in regrowth height after clipping in early fall, in addition to the differences in senescence are a clear indication that some genotypes continued growing and accumulating biomass under reduced temperatures and short photoperiod. Over the two years, the lowland accessions showed higher regrowth height and lower senescence than intermediate and upland accessions (Figure 2). This is a clear indication that the lowland accessions exhibit a delayed onset of seasonal dormancy. The high correlation between NDVI and senescence percent based on image analysis $(r=-0.92)$ suggests that NDVI is an effective tool to quantify senescence and can be used as a substitute to the laborious and time-consuming image analysis procedure. Plants showing high senescence \% will have a low NDVI reading and plants with low senescence will have a high NDVI rating.

The differences in spring regrowth date are also an indication of the variability in the duration of winter dormancy between accessions. The lowland accessions exhibited on average lower values for SRD suggesting that they exited dormancy much earlier than the intermediate and the upland accessions even though they remained actively growing much later in the fall as indicated by the regrowth height after clipping in early September. The earliest lowland accessions exited dormancy 12 days earlier than the earliest upland (day 64 vs. day 76 from January $1^{\text {st }}$ ). Spring regrowth initiation was negatively correlated with date for flowering, suggesting that the accessions that started growth early in spring had a later flowering time in the season. These accessions are predominantly lowland. On the other hand, flowering date showed a low correlation with regrowth height in the fall and senescence suggesting that flowering date may not be a reliable indicator of the onset of dormancy. Variability in the duration of the flowering period was reported, with northern ecotypes taking one week between the emergence of inflorescence to the beginning of anthesis, and southern ecotypes taking between 4 and 6 weeks [33]. Van Esbroeck et al. [34] found a delay in panicle emergence and a longer duration of panicle exertion in the upland switchgrass cultivar Cave-in-Rock when exposed to longer photoperiod and suggested that the delay was associated with increase in the period between the sequential emergences of leaves on the main stem of the plant. Flowering date also showed the lowest correlation with biomass yield compared to the other dormancy indicators. Fall regrowth height showed a high positive correlation with biomass yield, while spring regrowth initiation showed a strong negative correlation with biomass yield, suggesting that the accessions that underwent shorter durations of winter dormancy accumulated more biomass and therefore higher yield. 
Based on temperature and photoperiod charts (Figure 1), the ambient temperature in the study site declines below the favorable levels for warm season grasses around late August while daylight continues to decrease since early August. Evidences from studies attempting to establish the optimal time for switchgrass harvest point to early fall as the right harvesting time based on maximum yield and nutrient recycling [30] [31] [32] [35] [36] [37]. These findings provide indirect evidence for the window of end of growth and seasonal nutrient remobilization known to be connected to the onset of endodormancy. In a study measuring seasonal changes in $\mathrm{N}$ content in switchgrass, Wayman et al. [35] found the highest $\mathrm{N}$ content in above ground structures being in June and started to decrease from September until late fall while $\mathrm{N}$ concentration in below ground structures increased starting in August. Piecing together all this information, we rationalize that the window to phenotype the onset of winter dormancy in switchgrass is most likely the end of August and early September when temperature and daylength fall below the thresholds favoring growth, and when plants start remobilizing nutrients to the belowground storage organs.

The application of this phenotyping procedure will allow selecting a suitable combination of switchgrass germplasm with very short duration of winter dormancy or even non-dormant provided incorporation of cold tolerance to overcome the occasional freeze. Since the growing degree-days in the southeastern US are higher than the northern regions, it might possible to implement a management system based on multiple cuts per year instead of the traditional one harvest system leading to a significant increase in feedstock biomass yield.

Future research work will focus on identifying a set of standard checks with varying degrees of dormancy that can be used to standardize dormancy ratings across breeding programs. Winter dormancy appears to be quantitative, therefore genetic mapping of the underlying genetic loci and development of genomic resources will make selection more efficient.

\section{Conclusion}

$\mathrm{FRH}$ and senescence percentage appear to be reliable indicators of the onset of winter dormancy, whereby an accession that initiated dormancy early will have a low FRH and a high senescence percentage. Even though it is difficult to have an exact assessment of the duration of dormancy because it is hard to determine with precision the date of growth suspension, SRD can be used as a surrogate indicator of the duration. Combining the three variables in a selection index may provide a reliable tool to phenotype winter dormancy in switchgrass. The strong correlation of these variables with biomass yield makes them useful candidates for the manipulation of the duration of dormancy to increase the growing season and consequently improving biomass production. In southern regions with mild winters, it might be possible through intense selection to develop germplasm with much reduced dormancy or even non-dormant switchgrass germplasm. Incorporating cold tolerance would provide an insurance against potential ex- 
posure to infrequent low temperatures in the winter season of southern environments.

\section{Acknowledgements}

Partial Funding was provided by The Center for Bioenergy Innovation a US Department of Energy Research Center supported by the Office of Biological and Environmental Research in the DOE Office of Science.

\section{References}

[1] Romberger, J.A. (1963) Meristems, Growth and Development in Woody Plants: An Analytical Review of Anatomical, Physiological, and Morphogenic Aspects. Technical Bulletin No. 1293, United States Department of Agriculture, Forest Service.

[2] Schoot, C.V.D. (1996) Dormancy and Symplasmic Networking at the Shoot Apical Meristem. In: Lang, G.A., Ed., Plant Dormancy: Physiology, Biochemistry and Molecular Biology, CAB International, Wallingford, 59-81.

[3] Vegis, A. (1964) Dormancy in Higher Plants. Annual Review of Plant Physiology, 15, 185-224. https://doi.org/10.1146/annurev.pp.15.060164.001153

[4] Rohde, A. and Bhalerao, R.P. (2007) Plant Dormancy in the Perennial Context. Trends in Plant Science, 12, 217-223. https://doi.org/10.1016/j.tplants.2007.03.012

[5] Thomashow, M.F. (1999) Plant Cold Acclimation: Freezing Tolerance Genes and Regulatory Mechanisms. Annual Review of Plant Physiology \& Plant Molecular Biology, 50, 571-599. https://doi.org/10.1146/annurev.arplant.50.1.571

[6] Preston, J.C. and Sandve, S.R. (2013) Adaptation to Seasonality and the Winter Freeze. Frontiers in Plant Science, 4, 167-167. https://doi.org/10.3389/fpls.2013.00167

[7] Lang, G.A., Early, J.D. Martin, G.C., and Darnell, R.L. (1987) Endo-, Para-, and Ecodormancy: Physiological Terminology and Classification for Dormancy Research. HortScience, 22, 371-377.

[8] Junttila, O. (1988) To Be or Not to Be Dormant: Some Comments on the New Dormancy Nomenclature. HortScience, 23, 805-806.

[9] Lang, G.A. (1987) Dormancy: A New Universal Terminology. HortScience, 22, 817-820.

[10] Lang, G.A., Martin, G.C., Stutte, G.W., Darnell, R.L., Early, J.D. and Arroyave, N.J. (1985) Dormancy: Toward a Reduced, Universal Terminology. HortScience, 20, 809-811.

[11] Woo, H.R., Kim, H.J., Nam, H.G. and Lim, P.O. (2013) Plant Leaf Senescence and Death-Regulation by Multiple Layers of Control and Implications for Aging in General. Journal of Cell Science, 126, 4823-4833. https://doi.org/10.1242/jcs.109116

[12] Anderson, J.V., Gesch, R.W., Jia, Y., Chao, W.S. and Horvath, D.P. (2005) Seasonal Shifts in Dormancy Status, Carbohydrate Metabolism, and Related Gene Expression in Crown Buds of Leafy Spurge. Plant, Cell and Environment, 28, 1567-1578. https://doi.org/10.1111/j.1365-3040.2005.01393.x

[13] Sarath, G., Baird, L.M. and Mitchell, R.B. (2014) Senescence, Dormancy and Tillering in Perennial C4 Grasses. Plant Science, 217-218, 140-151. https://doi.org/10.1016/j.plantsci.2013.12.012

[14] Horvath, D.P., Anderson, J.V., Chao, W.S. and Foley, M.E. (2003) Knowing When to Grow: Signals Regulating Bud Dormancy. Trends in Plant Science, 8, 534-540. 
https://doi.org/10.1016/j.tplants.2003.09.013

[15] Casler, M.D., Stendal, C.A., Kapich, L. and Vogel, K.P. (2007) Genetic Diversity, Plant Adaptation Regions, and Gene Pools for Switchgrass. Crop Science, 47, 2261-2273. https://doi.org/10.2135/cropsci2006.12.0797

[16] Christensen, C.A. and Koppenjan, G. (2010) Planting and Managing Switchgrass as a Dedicated Energy Crop, 2nd Edition. Blade Energy Crops, Kluwer, CERES Inc., Los Angeles, CA.

[17] Lowry, D.B., Behrman, K.D., Grabowski, P., Morris, G.P., Kiniry, J.R. and Juenger, T.E. (2014) Adaptations between Ecotypes and Along Environmental Gradients in Panicum virgatum. American Naturalist, 183, 682-692. https://doi.org/10.1086/675760

[18] Casler, M. (2012) Switchgrass Breeding, Genetics, and Genomics. In: Monti, A., Ed., Switchgrass, Springer, London, 29-53. https://doi.org/10.1007/978-1-4471-2903-5_2

[19] Aspinwall, M.J., Lowry, D.B., Taylor, S.H., Juenger, T.E., Hawkes, C.V., Johnson, M.V.V., Kiniry, J.R. and Fay, P.A. (2013) Genotypic Variation in Traits Linked to Climate and Aboveground Productivity in a Widespread C4 Grass: Evidence for a Functional Trait Syndrome. New Phytologist, 199, 966-980.

https://doi.org/10.1111/nph.12341

[20] Kszos, L.A., Downing, M.E., Wright, L.L., Cushman, J.H., McLaughlin, S.B., Tolbert, V.R., Tuskan, G.A. and Walsh, M.E. (2000) Bioenergy Feedstock Development Program Status Report. Publication No. 5049, Environmental Sciences Division, Oak Ridge, TN.

[21] McLaughlin, S.B. and Kszos, L.A. (2005) Development of Switchgrass (Panicum virgatum) as a Bioenergy Feedstock in the United States. Biomass and Bioenergy, 28, 515-535. https://doi.org/10.1016/j.biombioe.2004.05.006

[22] Parrish, D.J. and Fike, J.H. (2005) The Biology and Agronomy of Switchgrass for Biofuels. Critical Reviews in Plant Sciences, 24, 423-459. https://doi.org/10.1080/07352680500316433

[23] United States Department of Agriculture (2016) U.S. National Plant Germplasm System. https://www.ars-grin.gov/npgs/collections.html

[24] Acharya, A.R. (2014) Genetic Diversity, Population Structure and Association Mapping of Biofuel Traits in Southern Switchgrass Germplasm. Ph.D. Dissertation, University of Georgia, Georgia.

[25] Your Weather Service (2017) U.S. Climate Data. https://www.usclimatedata.com/

[26] U.S. Naval Observatory (2011) Astronomical Applications Department. http://aa.usno.navy.mil/index.php

[27] Lamari, L. (2008) Assess 2.0. Image Analysis Software for Plant Disease Quantification. APS Press, St. Paul, MN.

[28] Trimble Ag Field Solutions (2017) GreenSeeker Handheld Crop Sensor. https://agriculture.trimble.com/precision-ag/products/greenseeker/

[29] Benedict, H.M. (1940) Effect of Day Length and Temperature on Flowering and Growth of Four Species of Grasses. Journal of Agricultural Research, 61, 661-671.

[30] Adler, P.R., Sanderson, M.A., Boateng, A.A., Weimer, P.J. and Jung, H.J.G. (2006) Biomass Yield and Biofuel Quality of Switchgrass Harvested in Fall or Spring. Agronomy Journal, 98, 1518-1525. https://doi.org/10.2134/agronj2005.0351

[31] Johnson, J.M.F. and Gresham, G.L. (2014) Do Yield and Quality of Big Bluestem and Switchgrass Feedstock Decline Over Winter? BioEnergy Research, 7, 68-77. https://doi.org/10.1007/s12155-013-9349-9 
[32] Gamble, J.D., Jungers, J.M., Wyse, D.L., Johnson, G.A., Lamb, J.A. and Sheaffer, C.C. (2015) Harvest Date Effects on Biomass Yield, Moisture Content, Mineral Concentration, and Mineral Export in Switchgrass and Native Polycultures Managed for Bioenergy. BioEnergy Research, 8, 740-749.

https://doi.org/10.1007/s12155-014-9555-0

[33] McMillan, C. and Weiler, J. (1959) Cytogeography of Panicum virgatum in Central North America. American Journal of Botany, 46, 590-593. https://doi.org/10.1002/j.1537-2197.1959.tb07057.x

[34] Van Esbroeck, G.A., Hussey, M.A. and Sanderson, M.A. (2003) Variation between Alamo and Cave-in-Rock Switchgrass in Response to Photoperiod Extension. Crop Science, 43, 639-643.

[35] Wayman, S., Bowden, R.D. and Mitchell, R.B. (2014) Seasonal Changes in Shoot and Root Nitrogen Distribution in Switchgrass (Panicum virgatum). BioEnergy Research, 7, 243-252. https://doi.org/10.1007/s12155-013-9365-9

[36] Wilson, D.M., Heaton, E.A., Liebman, M. and Moore, K.J. (2013) Intraseasonal Changes in Switchgrass Nitrogen Distribution Compared with Corn. Agronomy Journal, 105, 285-294. https://doi.org/10.2134/agronj2012.0233

[37] Ashworth, A.J., Allen, F.L., Bacon, J.L., Sams, C.E., Hart, W.E., Grant, J.F., Moore Jr., P.A. and Pote, D.H. (2017) Switchgrass Cultivar, Yield, and Nutrient Removal Responses to Harvest Timing. Agronomy Journal, 109, 2598-2605. https://doi.org/10.2134/agronj2017.01.0018 